\title{
Democratization in India and Pakistan
}

\section{$(1999-2012)$}

\author{
Prof. Dr. Razia Musarrat \\ Professor and Chairperson, Department of Political Science \\ The Islamia University of Bahawalpur Pakistan \\ Muhammad Ibrahim (Corresponding author) \\ Lecturer, Govt. Post Graduate College \\ Bahawalnagar, Pakistan
}

Received: February 10, 2013 Accepted: March 25, 2013 DOI: 10.5296/jpag.v3i2.4001

\begin{abstract}
The democratic system is accepted and favored system in the contemporary world. It has the ability to consolidate the needs of the people's participation and reasoning in the legislative process. Effects to implement democracy in states are known as democratization. India and Pakistan adopted the democratic system. Pakistan has undergone a progression of nation-building and struggle for development of institutions for stable democracy. Indian and Pakistani politicians as well as public have important role democratization. Free and fair elections are prerequisite for democratization. The state must rehearse the norm of equivalent citizenship irrespective of religion, caste, ethnicity and regional background. Many states of civilized world are unable to fulfill commitment merely rhetorical. Democratic mechanism is used to control over power of state organ to contraption non democratic agenda. The leaders are so fascinated in their power game that they are not agitated about the inquisitiveness and prosperity of the common people. Such a perception of low political effectiveness is replicated in the lessening voting proportion in the general elections.
\end{abstract}

Keywords: Democratization, violence, rule of law, elections 


\section{Introduction}

India's demography has a different symmetry in composition. The population of Utter Pradesh state is 116 million as compare to Skkim with 540493. Rajasthan have 342239 square kilometers and Goa have 3702 square kilometers. Andoman and Nicobar Island are small. There are huge disparities of linguistic, ethnic, communal and economic situation within and across the states. Many tribes, communities were fighting for their identities issues. There are many ethnic movements in states with federal government for autonomy. ${ }^{\mathrm{i}}$ Pakistan consists of Punjab, Sindh, Baluchistan, Khyber Pukhtoon Khwa, Ghulget Bultistan and FATA.

India made its first constitution in 1950 while in Pakistan in 1956. First competitive general elections held in 1952 in India and in 1970 in Pakistan. Democratization process of India and Pakistan started according to modern democratic norms.

India managed to conduct the general elections after proper interval. ${ }^{\text {ii }}$ The majoritarian democracy has itself less capable of handling problem of multicultural heterogeneous societies. The institutions of representative democracy designed for homogenous societies. The political system for governance in India may sometime fail to give fruitful results. Coalition government remained to fail to provide the governing system for full tenure.

Pakistan had to face challenges in institutional and constitutional development for democratic process. Political parties were not mature and media had no effective role in the society to develop the awareness about the rule of law. The rule of law bound different segments to co-ordinate for the democratic government. Without representative parliament it was hard task to develop the democratic institutions. The frequent military intervention affected the process of democratization and institutional development in Pakistan. The validation of military coups created the challenge for Judiciary of Pakistan. It was critical situation for judiciary to validate or not. In this situation judiciary validate the coup in the view of controversial jurisprudential source. ${ }^{\text {iii }}$ Pakistan Superior Court introduced controversial approach on the base of the Professor Kelsen's Theory of revolutionary legality. ${ }^{\text {iv }}$ Judiciary had a specific and vital role in the development of democratization. The decisions of courts were followed in the political governing system. There were many landmark judgments in the response of validity, legitimacy and legislative capacity of extra-constitutional regimes. The questions arose about political validity, which shows the personal integrity of Judges. There are political implications of their sweeping holdings. ${ }^{\mathrm{v}}$

\section{Atal Bihari Vajpayee Regime in India}

B.J.P led coalition government was failed and thirteenth general elections held in September1999.There was small scale war fought between India and Pakistan on Kashmir issue. Ultimately India made his position better at Kargil front. There was a wave of party popularity in the country due to Kargil situation. The situation benefited B.J.P and its allies in election campaign. N.D.A obtained 303 seats in which B.J.P had 183 seats. Now B.J.P enjoyed full term federal government. National Democratic Alliance formed government on October 22, 1999. ${ }^{\text {vi }}$

It was said that Pakistan and India had been sponsoring violence in dubious Indian state of 
Jammu and Kashmir. It was using as appliance in the foreign policy from the last decade between two States. In Indian political history several time extraordinary laws were figured. It was first time it made manifesto in the election campaign of B.J.P in election February 2002 of U.P assembly. As B.J.P wanted figuration of POTA in U.P reflected the manners in which Indian democracy contested to resolve hegemonic ally. It was not articulated with such confidence and justification. It was admitted the need of debate on such preventive detention laws. There was proper and judicial process of detention powers within the boundaries of legality. It was need to observe the human rights. The violations of human rights are against the basic spirit of constitution of India. A person in the cyclic process of arrests and re-arrests under the threat of security of state, law and order are ritual chant which were justified repressive legislation. ${ }^{\text {vii }}$ Extraordinary laws were undemocratic and indicative efforts in the development of rule of law practices were failed. It was used to suppress the political opposite. ${ }^{\text {viii }}$

TADA had implemented two times in India. TADA was extraordinary law since Independence. Under TADA Act 76000 persons were arrested till June 30, 1994. The cases of $25 \%$ were dropped, $35 \%$ were brought under trail but ended in acquittals. TADA was lapsed in 1999 after four years of accomplishment. In 1995 the cases were registered under the TADA Act and only 4958 cases were complete trailed. ${ }^{\text {ix }}$ When debate was started on POTO. It was abuse law which was constituted to block the terrorist act. ${ }^{\mathrm{x}}$ There was attack on Indian parliament on December13, 2001.Indian government declared that it was attack on the democracy of India. It was considered as 9/11 attack of U.S.A ${ }^{\mathrm{xi}}$. Indian government also wanted to widen analogous policy against terrorism. In this response POTA ${ }^{x i i}$ Act was promulgated in India.

The government focused on fiscal policy, small-scale industry, privatization, labor law and agriculture. In 2001 government started privatization but in the response unions resisted. N.D.A government continued past government of P.V. Narasimha Rao. To provide job opportunity government focused on the small industries development. B.J.P government adopted the mixed policies of conservatism, social conservatism, modern, enlighten and progressivism, for the aspiration of modern India. B.J.P government at center and state level gave importance to development of basic infrastructure for masses aspiration and facilitation. On Kashmir issue it adopted and declared it as internal matter of India.

There was intolerance in social system of India in which dalits are hampered by obnoxious and impalpable barriers of custom and tradition. It was paradoxical that dalits do not have freedom to worship in the Hindu temple. Article 15 of the constitution outlaws discrimination on grounds of religion, race and caste. The dalits caste was barring entry into temple proscribed due to un-touch ability. India was afflicted under the caste system and millions of peoples exaggerated under the caste propagandists who claim sanction from scriptures. A section of political class argue that since legal and constitutional provision exist to deal with caste based disabilities and discrimination.

It was not realize the social and religious rights of dalits; legal frame work had no answer about it. It has no effective response after making internationalization about caste system. There should be socio-political movements led by the reformers. It may be said that Hindu 
religious head and political class for the realization of these rights. The ruling party BJP and allies should take a lead to solve the issue of caste system. It was solve under the good will not than political gain of vote bank. It was made effective with right of speedy trail, deterrent and prompts when dalits are victims of violence. It realized under justice system. The rule of law helps in solving the issue. The laws are remnants dead under the corruption of political class, due to apathy and unconcern. The interpreting and enforcement of law by the agencies has its explicit role. The social reformers, vigilant citizen bodies, political segments of polity should step into launch the movements of awareness in the peoples for the dalits rights.

There were security issues in North-East Indian States. Federal government involved in solving the ethnic movement issue. In Teri Pura State National Security Act was implemented on January 6, 2000 to curb the insurgency in the state. It was interference in state affairs which was against the democratic norms. The Indian constitution had provision to involve in state security.

The announcement of performing the religious ceremony was at disputed site of Ayodhya by Vishwa Hindu Parishad arise tension. The railway train was burnt in Godhra Gujarat on February 27, 2002 and 59 Hindu activists burnt. There were retaliatory attacks against Muslims. Argument was made that it was a planned conspiracy. There was extreme violence between Hindu and Muslims in Gujarat state under B.J.P rule in 2002. It was reported that 790 Muslims and 254 Hindus were killed and 223 peoples were missing in these riots. 298 dargahs, 205 mosques, 17 temples and 3 churches were smashed. 61000 Muslims and 10000 Hindus left their homes and fled away. In the preventive measure 17947 Hindus and 3616 Muslims were arrested. It was claimed that State government administration involved in 2002 riots. ${ }^{\text {xiii }}$ N.D.A government elected A.P.J Abdul Kalam as eleventh President of India on July 25, 2002. Gujarat issue was prolonged and not investigated completely and impartially. The Supreme Court of India set up Special Investigation Team in April 2009 to investigate the Gujarat riot cased brought under the notice of Honorable Court.

The corruption stories came on the panorama often in India. In 2001 there was corruption and sex scandal which exposed by Tehelka. B.J.P President Bangaru Laxman and army officials were accused for the arms transaction. Political leader caught by the video-tape taking bribe did not admit the fault of crime. The corruption scandal was exposed the democratic leaders of Indian democracy. Investigative journalists have to draw the red line where journalistic ethics should end.

India was replete with scandals of corruption and financial wrongdoing which run into hundreds of thousands of crores with ruling classes in league with the business class. The Bofors gun, HDW submarine deals, Tansi land deal, JMM Bribery, Harshad Mehta, Ketan Parikh's stock market scams, Tehelka's exposure of corruption in political and army establishments, the UTI scam have all bled the nation's economy. ${ }^{\text {iv }}$

The situation was similar in Pakistan. The situation of Pakistani institutions was poor which curb the corruption. The accountability, transparency, rule of law and responsiveness are basic characteristics of democratization. In the corruption scandals situation was similar in Pakistan and India on same scale. 
The democratic institutional and cultural normative are to suppress corruption. The effects and dimensions of both institutions and culture are different about the corruption. The role of public participation is effective in detecting and punishing corruption. In democratic process, freedoms of demand to inquire questions, speech, press, demand inquires and publicize are basic elements. The corruption scandals arose in the government organs, it is stressed to prosecute and punish the miscreants. It is sensitive and responsible duties of elected officials to hold hearings according to legal process. The democratic institutions effectiveness depends upon the set of democratic norms for curbing corruption. Rose- Ackerman focused on structural incentives and recognizes, "Economic approach to politics.... cannot explain the organization and transmission and transmission of the democratic and personal ideals require preserving a functioning mixed economy."xv

She further argued explicitly, if one wants to understand the functioning of democracy, it will not be possible to follow the conventional economist's inclination to ignore moral constraints upon self-seeking behavior and such kind of political virtue and moral beliefs are necessary in both public and politicians. ${ }^{\mathrm{xvi}}$

Judicial Commission was working about the demolition of Babri Masjid under the supervision of G.T. Nanavati. On the other hand ex-official of I.B claimed that RSS, BJP and V.H.P planned to demolish the Masjid. Liberhan Commission made 68 peoples responsible for the demolition of Masjid. Top leadership of BJP including A.B. Vajpayee, Kalyan Singh Chief Minister of UP, Murli Manohar Joshi, L.K Advani and some bureaucrats were involved in this incident. It was result of public awareness and developed democratic institutions.

N.D.A government which was headed by B.J.P formed a National Commission to review the working of the constitution in 2000 in the term reference stated, "The Commission shall examine..... smooth and effective governance..... within the framework of parliamentary democracy and recommend changes... without interfering with its basic structure." ${ }^{\text {xvii }}$

The reference to parliamentary democracy and basic structure were not changed and there was no alternative as Presidential system may be considered for alternative. In Delhi leaders come to terms with fact that India was committed Parliamentary system of government. ${ }^{\text {viii }}$

India was painstaking replica of democratic states. The democratic institutions were functioning appropriately. India society was based on discrimination, class and groups. It was pessimistic impact on Indian democracy‘s face. To some extent Pakistan has group divisions on some factors. In modern democracy all the citizen of the state have equivalent rights.

\section{Congress Regime 2004}

B.J.P government conducted the fourteenth general election in 2004. This election was contested under the two alliances N.D.A and U.P.A. After the election results it was hoped that Sonia Gandhi chairperson of Congress party to be Prime Minister. Sonia was under detractor due to Italian birth. Sonia Gandhi nominated Manmohn Singh as Prime Minister from the UPA. It was seen that in long career of administration in the government at different responsibilities performance. He was considered as untouched by the taint of corruption. He was looked as clean politician. ${ }^{\mathrm{xix}}$ Dr. Manmohn Singh was elected as Prime Minister. ${ }^{\mathrm{xx}}$ The fourteenth Rajya Sabha functioned from May 22, 2004 to February 26, 2009. 
NDA was defeated in election2004 due to regional politics and alliances made by BJP at different state level. There are 28 states in India. The allies in Andra Pradesh and Tamil Nadu made loss for BJP. UPA got 222 and BJP got 189 seats. $^{\text {xxi }}$

It was credit of Manmohn Singh government that election held peacefully in Punjab for Provincial Assembly. In election Shiromani Akali Dal won 48 seats and BJP won 19 seats. Congress could gain only 44 seats and was defeated. It was close competition between parties. Punjab province was fully involved in political system. In India many states were disturbed due to ethnic movements. In Punjab Khalistan Movement was remained in full swing. Democratization had limited the flames of such movement. This movement started in Congress government in1980s and now ended in Congress Raj.

It is seen from history of India that congress favored farmers, labors' unions and ethnic minorities. Party implied progressive income taxes and opposed unregulated business. The party had adopted centrist economy and social democratic system. In the present era congress has manifesto of secularism, new-liberalism, populism and free enterprise system. Manmohn government is doing job for eradicating poverty, illiteracy which strengthen democratic system.

Right to Information Act 2005 was imposed to make government transparency in the policy matter. Under the RTI Act every individual has right to gain information. Every individual could move about the deals and corruption of public departments. The malpractices are covered under the use of secrecy in government departments. To eliminate the corruption RTI Act had impacts on the political system. There were scandals in the arms deal in India. ${ }^{\text {xii }}$ It was also determined in Indian Supreme Court that liberty of speech and expression carries with it the right to assemble information. ${ }^{\text {xiii }}$ Indian National Congress party elected Pratiba Patil as twelfth President of India.

\section{Congress Rule and General Elections 2009}

General elections were held in 2009 and BJP was defeated by UPA. These elections were the largest elections of the world. In this election BJP got only 116 seats. Indian parliamentary system became as model for other countries. Singh government gave magnitude to parliament for the legislation process. During this tenure some important bills were passed as given; National Rural Employment Guarantee Act, , Revision of POTA, after Mumbai attacks 2008 Unlawful Activities (prevention) Act, Right of Children to Free and Compulsory Education Act.

The Singh government completed a plane to focus on the lower and middle classes of Indian society. In August 2005 NREGA bill was passed under which it was guaranteed that every rural unemployed member would get hundred day work. This plane was implemented in 200 districst of India. Durring next two years it will spread throughout the country. The government funded institutions for higher education to reserve $27 \%$ spaces for the backward castes. $^{\text {xxiv }}$

Anna Hazare started agitation against the corruption in India. His demand was to formulate the bill to stop and punish the corrupt leaders. Anna Hazare started the fast against state corruption. At this government gave response and a joint draft committee was constituted. It 
was for Jan Lokpal Bill. Government draft was presented by five ministers but the bill did not cover the corruption which affected the common man. There was corruption in working of Panchayat, in the ration of poor, in the daily wages of NAREGA. The ministers were asked that bill should have to cover the government employees. 30000 crore ration subsidy given to deprived peoples from which $80 \%$ was distorted. The works of schools, hospitals faced corruption was not sheltered under the bill. The current bill of government has different flaws. ${ }^{\mathrm{xxv}}$

India started negotiations with America for the agreement of civilian nuclear agreement. These attempts brought fruit and agreement signed on October 10, 2008. ${ }^{\text {xxvi }}$ Pranab Mukher Jee was designated as thirteen Presidents on July 25, 2012.

In India two governments were knocked down without vote of confidence in 1979 and 1996. In 1979, 1991, 1996 and 1998 Prime Ministers had to resign without facing the confidence motion. They had not majority in the Lok Sabha.The success of Indian democracy based on the bicameral house of legislature. Both houses were performing time to time contribution for the federal structure of India. 1950, 1951 and 1986 Rajya Sabha resolved the issue of two third majorities which was vested into constitution undermining legislative federalism. ${ }^{\text {xxvii }}$

Forty second amendment to the Indian Constitution in 1976. Several edict principles were introduced based on the unambiguous recognition. The accessible political system and legal frame work did not enough to lock identical justice and access to lawful remedies. These new provisions have served as dominant basis for the enlargement of human rights jurisprudence. It enhanced the accountability of state for the citizens.

\section{Pervez Musharraf Regime in Pakistan}

October 12, 1999 in Pakistan elected Prime Minister Nawaz Sharif was dismissed by General Pervez Musharraf. He staged coup and ousted the elected government. ${ }^{\text {xxviii }}$ After pursuant the Provisional Constitutional Order No 1, he assumed the title of Chief Executive of Pakistan and announced his seven points agenda. The new government led by Musharraf justified take over Supreme Court in Zafar Ali Shah case under the doctrine of necessity. The court also directed to conduct the election within three years to restore democracy. ${ }^{\text {xix }}$ He was another military leader who took over the power and declared the politician were corrupt, the elected government failed to perform in the public interest, economy was to collapse, law and order situation was worse and opposition was oppressed.

Ousted Prime Minister and his party leaders filed different petitions in Supreme Court against the military coup of October 12,1999 . The petitions prayed for restoration of government and assemblies under article 184 (3) of constitution 1973. Petition was fixed for hearing in superior court on January 31, 2000. There was possibility of adverse findings by Supreme Court. General Pervaz Musharraf issued order No 2000 for oath of judges of Superior Court of Pakistan. On January 26, 2000 Musharraf government asked the judges to take oath under P.C.O. ${ }^{\mathrm{xx}}$ Chief Justice of Pakistan was not allowed to go to court. Either Chief Justice of Pakistan persuaded other judges and may pass an order against PCO. Six from Supreme Court and 83 High Courts judges took oath. Mr. Irshad Hasan Khan was appointed new 


\section{Macrothink}

Chief Justice of Pakistan. In May 12, 2000, Supreme Court of Pakistan headed by Chief Justice validated coup of Musharraf and gave power to amend constitution. The Court declared dismissal of COAS by ousted Prime Minister as void and no legal effect. The opposition expressed disappointment on the decision. ${ }^{\text {xxi }}$

National Accountability Bureau was formulated by the Ordinance 1999 to arrest, punish and disqualifying the guilty from holding public office and contesting elections. NAB was accused to create P.M.L-Q at the cost of clearing mainstream political parties leaders instituting cases against them. Strong opposition candidates were keeping away from the elections by securing their disqualifying through Accountability Courts. Their cases were freezed against those who cracked under pressure and joined P.M.L-Q. In August 2002 PPP's 24 and P.M.L-N's 33 candidates were investigated. ${ }^{\text {xxii }} 64$ investigation cases were arbitrarily closed in the same year under the discretionary powers of the Chairman of N.A.B.

The manipulation of political parties under institutional powers was against democratization. The involvement of military bureaucracy in governing system effected political system of Pakistan. Indian military has no involvement in political system.

Table No 1

Status of Investigation against Politicians (2002)

\begin{tabular}{|l|l|l|l|l|}
\hline & Authorized & Completed & Under Process & Closed \\
\hline Punjab & 135 & 39 & 58 & 38 \\
\hline Sindh & 90 & 46 & 42 & 2 \\
\hline Khyber Pukhtoon Khwa & 29 & 15 & 4 & 10 \\
\hline Baluchistan & 23 & 12 & 6 & 5 \\
\hline Rawalpindi & 33 & 5 & 19 & 9 \\
\hline Total & 310 & 117 & 129 & 64 \\
\hline
\end{tabular}

Source: National Accountability Bureau: Annual Report 2002

The infrastructure of accountability remained controversial NAB itself criticized on several counts. There was exclusion of serving officers of armed forces and judiciary from NAB's jurisdiction. It structural approach towards corruption and introduction of measures were controversial. The Chairman of NAB had discretionary power under NAB ordinance section-9 to close or registered case against someone. It did not fulfill the democratic principles. In India such institutions were never formulated. 
Table No 2

Status of References Filed (2002)

\begin{tabular}{|l|l|l|l|l|l|l|}
\hline Provinces & $\begin{array}{l}\text { Cases } \\
\text { Filed }\end{array}$ & $\begin{array}{l}\text { Cases } \\
\text { Decided }\end{array}$ & $\begin{array}{l}\text { Case } \\
\text { Convicted }\end{array}$ & Acquittals & Withdrawn & $\begin{array}{l}\text { Pending/ } \\
\text { Under } \\
\text { Trial }\end{array}$ \\
\hline Punjab & 148 & 61 & 54 & 5 & 2 & 87 \\
\hline Sindh & 135 & 88 & 66 & 22 & - & 47 \\
\hline $\begin{array}{l}\text { Khyber Pukhtoon } \\
\text { Khwa }\end{array}$ & 75 & 41 & 32 & 9 & - & 34 \\
\hline Baluchistan & 103 & 89 & 85 & - & 4 & 14 \\
\hline Rawalpindi & 78 & 34 & 28 & 4 & 2 & 44 \\
\hline Total & 539 & 313 & 265 & 40 & 8 & 226 \\
\hline
\end{tabular}

Source: National Accountability Bureau: Annual Report 2002

For the sack of accountability it was hour of need to establish a transparent and impartial institution to pervasiveness of corruption in Pakistan. The deep rooted popular feelings of resignation to its inevitability opened up space for the military government. The military government cultivates and projected this issue publically at main scale for the legitimacy on the public forum with a vengeance. From 1990s corruption issue was became to feel obliged to prioritize in both the electoral campaigns and domestic policies.

It was asserted that structural reforms were required in overall fields of life. The prior government was incompetent of devising and incapability replaces the sham democracy to true democracy. June 26, 2002 NRB published proposals of LFO of proposed 78 amendments in 29 articles of constitution. The proposals were drafted to premise that absence of checks and balance led to unjustified enlargement of power in office of Prime Minister. There was wide range of powers for president. The decisions of PM and his cabinet were not binding to president. There was a consultant forum of NSC on the matters pertaining sovereignty, integrity and security of state system of centralized democracy and governance, confiscation of federal and provincial cabinets, suspension of national and provincial assemblies and assertion of state of emergency. NSC consisted of Chiefs of forces, Chairman of Joint of Staff, PM, Chief Ministers of Provinces and President. ${ }^{\text {xxiii }}$ Legal Framework Order 2002 was promulgated on August 21, 2002. He also inserted the article (58) (2) (b) through executive order in the form of legal framework order. The fresh elections were held after changed in the governing system. Next he claimed the power given by Supreme Court when validated take over.

The LFO change parliamentary character of constitution. It was legitimized under $17^{\text {th }}$ 
amendment with the help of religious political parties. LFO was rejected unanimously. The Supreme Court Bar Association, Pakistan Bar Council and the lawyers observed a black day on August 27, 2002 against the promulgation of LFO. The legal community held the government responsible for low level political activity. It was deliberately creating confusion and uncertainty about the election. It accused government of depoliticizing the election process. Government was making effort to singling out major political parties from the election. Government lifted ban from the political activities. ${ }^{\text {xxiv }}$ The HRCP vehemently made critic in unconcealed mode that electoral process is being vulgarized. The interest and will of people was not preference in electoral process. ${ }^{\mathrm{xxv}}$

In India POTO Act promulgated under BJP government. There was huge cry by the opposition and media against it. It said that it was an extra ordinary law in Indian history. Other the side in Pakistan, Superior Court of Pakistan awarded the powers to amend constitution which was function of parliament. The apex court which was product of Constitution 1973 empowered someone other than the properly constituted legislature under the same constitution to effect changes in it.

\section{Pakistan's Presidential Referendum 2002}

The political situation was remaining polarized between the civil and military leaders. The political scene either favors one or other. General Musharraf took over the power of government. The pressure built up on the President Mohammad Rafiq Tarar to resign. He resigned in June, 2001. Musharraf started consolidating power. He appointed himself as a President of Pakistan on June 20, 2001 for five years before going to India in July 2001. After Supreme Court legitimacy for public legitimacy referendum was held on April 30, 2002.

According to Pakistan Election Commission $\quad 70 \%$ voter cast vote. The citizens challenged the referendum under article 184 of constitution but Supreme Court of Pakistan dismissed all these petitions on April 27, 2002 as premature. ${ }^{\text {xxvi }}$ The major political parties appeal to the public for boycott the poll and denounced the results as a fraud. The civil society organizations were also joined. The Human Right Commission of Pakistan had also expressed opposition to the referendum and declared it was blow to democratic foundation of Pakistan and pushed towards the abyss of absolute rule that consequently threatened human rights. ${ }^{\text {xxxvii }}$

Legal community also exhibited the proactive role in the opposition of referendum. From the Election Commission Justice Tariq Mehmood had resigned on April 6, 2002 to protest against referendum. The Government was quick to press the Justice to issue a disclaimer. The pressure brought to bear on Justice Tariq led to resignation from the Baluchistan High Court. ${ }^{\text {xxviii }}$ PPP and PML-N rejected the results. It was said to Musharraf to step down immediately and no moral and political authority to continue for governance.

The issue of Devolution of Power Plane attracted people. It was under debate from several decades. It represents the societal inputs into decision making at local level. It was method to lower the cost of administration to lower level to save the people's time. This approach needs to be contextualized in the political system.

According NRB came up with Local Government Plan 2000 with promised major changes in 
the system of governance. This Ordinance put into operation through promulgation LGP Ordinance issued by the provincial governments in August 2001. Local bodies election was held in five phases started from December 30, 2000. Through this election elected Councilors by direct election and Nazims, Naib Nazam elected indirect election. It was fully installed on August 14, 2001.

It was considered that further five years by conducting a referendum not warranted by constitution. Pervez Musharraf took a vote of confidence on January 1, 2004 from the electoral college of Pakistan of National Assembly and Provincial Assemblies.

\section{Transition to Democracy in 2002}

According to the decision of Supreme Court elections would have to hold till October 2002. General gave road map plane for the transition of democracy. He issued ordinance for the implementation of devolution plane. Multi-steps election schedule was announced for local level system of government. In the transition period it was the need to supervise carefully the process of election would be free and fair. Here the situation was reverse, the election were rigged in the favor of Islamic minded parties in Khyber Pukhtoon Khwa and Baluchistan. After 9/11 the victory of Islamic minded parties reckon in Pakistan and validating the perception about the power of pro-Taliban in Pakistan.

The Army institution has capability to thwart and manage the situation in Pakistan. Elections were engineered and the results were unexpected. It was kept in view that democratic transition was happened but real power remained with Army. The policies and authority remained impervious to civilian challenge. The sovereignty of Parliament became question mark under the Legal Framework Order in which the power to dissolve the Assemblies, formation National Security and nonelected body keep the check and balance of the performance of elected government. MMA was able to form government in Baluchistan with PML- Q and Khyber Pukhtoon Khwa of its own. ${ }^{\text {xxix }}$

Elections held in October 2002 and political parties were participating in the general elections. On the other hand Professional associations, NGOs, madrasahs, women rights and human rights activists were more vocal in 2002 elections. In 2002 election campaign issues were women rights, Constitutional amendments under LFO and corruption, demand in increased in women reserved, repeal of Hudood Ordinance in which women were affected.

The elections were engineered and controlled by NAB which was controlling the election process from the main opposition parties. EC sought explanation from some bureaucratic. These overbearing bureaucrats showed some concern about the fairness of election. The blatant disrespect shown to the EC by such officials was symptomatic of the scant regard in the eyes of administration at higher levels. EC issued a Code of Conduct for the electronic media on August 8, 2002. It was described the election coverage on the state controlled media should be balanced, fair and unbiased in the respect of other things as symbols, banners, flags, party manifestoes etc. ${ }^{\mathrm{xl}}$ The military junta gained results according to his will. PPP gained 62 seats in the national assembly. 
Table No 3

Party position of election 2002

\begin{tabular}{|l|l|l|l|}
\hline Party & Votes (millions) & \%age & No. of Seats Won \\
\hline PPP & 7.39 & 25.01 & 62 \\
\hline PML-Q & 7.33 & 24.81 & 77 \\
\hline PML-N & 3.32 & 11.23 & 14 \\
\hline MMA & 3.19 & 11.10 & 53 \\
\hline
\end{tabular}

Source; Pakistan Election Commission

After the elections 2002 pro-Musharraf PML-Q newly created party nominated his candidate for Prime Minister from Baluchistan Zafar Ullah Jamali. Chief Executive Musharraf transferred his some powers to Prime Minister. ${ }^{\text {xli }}$ The Provincial governments were established in November-December. Senate was elected in the end of February 2003 and resumed functioning on March 12, 2003. It was time when all the Constitution of 1973 was restored with the amendments of LFO. Pakistan came back with elected governments. All the political system was controlled by the President of Pakistan and Army Chief with unusual combination of in a democratic polity. This situation gave him overriding clout in the polity.

PPPP made alliance with PML-Q to form government. After election MMA did not join the alliance of formation of government. President still required two third majorities to pass the LFO at the name of seventeenth amendment which would change the character of constitution parliamentary to presidential form.

In the start MMA with other opposition parties of PML-N and PPP jointly refused the LFO and demand resignation of Musharraf under the banner of Alliance of Restoration of Democracy. ${ }^{\text {xlii }}$ MMA became instrument of support to the government, LFO passed. MMA announced that Musharraf promised to resign as Chief to December 31, of next year. ${ }^{\text {xliii }}$

Issue of nuclear proliferation had critic situation for the military rule. USA and the West raised question about the sharing of nuclear technology to other countries. Pervez Musharraf was dismissed as Science advisor in January 2004. Mostly peoples were not admitting the official point of view about the issue.

Zafar Ullah Jamali resigned on June 26, 2004. Chaudary Shujaat Husain was appointed as new Prime Minister of Pakistan. Shaukat Aziz was nominated as a next Prime Minister. ${ }^{\text {xliv }}$ It was not according to the will of people. It was authoritarian pattern of government in which one man controlled the transition process. It was seen as democratic regime and all democratic instruments were working. Here it could be easily noted the transition process was designed in such a way that power sharing was with the section of political leaders and not to civilian political leaders.

It was supposed and thought that an arbiter role may be attributed to MMA. MMA was a 
dependent variable in the political system. On the other hand MMA tried to enlarge the political space defined by the military bureaucracy. It was considered in no matter would be the master of destiny. The situation of relationship became stern between MMA and military bureaucracy. Now the military bureaucracy was not needed the MMA and its role lessened in the local bodies elections 2005 .

Supreme Court started hearing the madrassa degree disqualification case. In running election should have to pass the additional exams in English, Urdu and Pakistan Studies. It was observed decision was against the regime of Chief Minister of Khyber Pukhtoon Khwa and the leader of opposition to end boycott of NSC. ${ }^{\text {xlv }}$ MMA itself was helped in the institutionalizing NSC by constitutionally. In this way army presence and control in the political system became permanent figure constitutionally. The military bureaucracy always politically gained much more than Islamist.

Even protest against democracy restriction, but provide support whatever military was needed. MMA became popular antipathy channel when government's action did not equivalent its public speaking. MMA leader believed about the resignation was a matter of debate. This debate between the parties was not made public; there were some issues which might be settling down. Those were Hudood Laws, Code of honor that regulates male, female relations as well as marriages. To repeal the Hudood Ordinance of Zia authoritarian rule, Pervez Musharraf government decided to legislate about the protection of women. Pakistani parliament was legislated Women's Protection Bill in November 2006. Under the Hudood Ordinance raped women should have to provide four witness of rape.

The political situation was unstable in Baluchistan. Some political activists demanded for the right of national resources of their province Baluchistan. Pakistan army was developing army infrastructure for the defense process. Mean-while Dr. Shazia Khalid rape case came on the scène on March 2005. Akbar Bughti gave strong response at this issue. ${ }^{\text {xlvi }}$ Later on Akbar Bughti was murdered in den on August 26, 2006 by the army operation. This incident changed the political situation of Baluchistan province. With the passage of time situation became worse. Baluchistan's instability was not improved till the last days of military rule.

Pervez Musharraf suspended Chief Justice Iftikar Muhammad Chaudhary on March 9, 2007 under the reference sent by Prime Minister. The corruption charges pressed against Chief Justice in reference. Justice Javed Iqbal was appointed as Acting Chief Justice. Pervez Musharraf's decision sparked protest among the lawyers. From March 12 a campaign started for the restoration of Chief Justice Iftikar Muhammad Chaudhary. Hundreds of lawyers at different cities like Islamabad, Karachi, Quetta and Lahore protested in black dresses. Chief Justice of Pakistan Iftikar Muhammad Chaudhary was reinstated with unanimous decision on July 20, 2007.

President Pervez Musharraf imposed emergency on November 3, 2007 in Pakistan due to conflict with judiciary, political and governing issues. The constitution was suspended again. Full bench of Supreme Court of Pakistan gave decision not to oath under new PCO. The judges of Superior Court of Pakistan were called for new PCO oath. The Judges of High Courts and Supreme Court were detained. President Pervez Musharraf imposed restrictions 
on electronic and print media of Pakistan.

Professional consensus, Islamic traditions, and the constitution all indicated that Pakistan Supreme Court will deliver a bold decision in case of Chief Justice vs. President of Pakistan to end the military blitz for independent judiciary. Pakistan Supreme Court understands that any waffling, hair-splitting, or technical hedging in opinion will only encourage this and future presidents to sponsor a judicial culture of timidity and subservience. An unequivocal annulment of President's Reference against the Chief Justice of Pakistan (CJP) is needed to restore the dignity of judiciary.

Lal Masjid and adjoining madrassa for women Jamia Hafsa became issue and created strange situation in Islamabad. From January 2007 administration of Masjid started a parallel decision. They conducted raid against brothels, corrupt police official and suspected prostitutes. It was said that in April 2007 Islamic Court was setup. Till July 2007 there was confrontation in the government and administration of Lal Masjid.

\section{Presidential Election 2007}

President General Pervez Musharraf wanted to continue his regime. But the media and judiciary were creating hurdles in re-electing as a president. He made plane to elect from present assembly. Presidential election was held in Pakistan on October 6, 2007. Parliament elected Pervez Musharraf by an overwhelming majority. This majority was due to the absence of main stream political party leadership. Nawaz Sharif and Benazir Bhutto had attempted to return back to Pakistan. Nawaz Sharif was deported back into exile by the ruling government because it was the violation of agreement. Benazir Bhutto made dialogue with President Pervez Musharraf to return back to Pakistan for the participation in the general election. National Re-Conciliation Order was issued between the government and PPP leader Benazir Bhutto. Under this deal PPP leader Amin Faheem did not contest the presidential election. There was petition against Pervez Musharraf against the dual post held by him. The Superior Court permitted to re-elect by the existing (present) parliament. The Election Commission checked the papers of presidential candidate and approved list of presidential candidates on the October 1, 2007. Pervez Musharraf won the election by gaining 671 votes out of the 1170 .

The military assumed power repeatedly. The military reshaped Pakistani polity with accordance to its own. The military interference in political system created hurdles in steady growth and sustainability of democratic institutions. The military rulers abrogated or suspended constitution to gain legislative power. The efforts to get deep root in public became difficult. There was controlled democratic system of government in Pakistan in cover of military rule. The efforts were made to hand over a political system according to aspiration of peoples and political realities of country. The practice is made in Pakistan. There is no idea of practice of such pattern of government in India.

\section{Democratization and General Elections 2008}

It was transition towards democracy. After the presidential election federal government made mind to conduct general elections. The Federal Minister of Parliamentary Affairs Sher Afghan Niazi announced for general election of National and Provincial Assemblies on 
January 30, 2008. These elections were studies with interest as battle between Islamic and religious political parties and liberal parties in West. Many social scientists had opinion that these religious parties were dependent variable determined by army. The question was in minds what will be the future of MMA in this election. There was deal finalized between government and Pakistan Peoples Party. The amnesty was awarded to Benazir Bhutto in corruption cases at arrival in Pakistan on October 18, 2007.

Benazir Bhutto was assassinated in the suicide blast in public procession at Rawalpindi on December 27, 2007. There were riots spread throughout the country. Benazir Bhutto's assassination changed the political scenario and PPP curb sympathy from public. Many people were died in the riots. Government post pond general elections due to violence throughout country. Different political parties participated in election at different manifestos. Some parties boycotted general election 2008. NRO agreement was signed between General Pervez Musharraf and Pakistan Peoples Party. The elections 2008 were held in specific situation, assassination of Benazir Bhutto and war of terrorism in Afghanistan and participation of exile leaders. PML-N took oath from all his contesting candidates for restoration of Judges of Superior Courts. Pakistan People's Party, Pakistan Muslim League-N, MQM, Pakistan Muslim League-Q ANP, JUI and some other parties took part in election.

Some parties as Jamaat-e-Islami Pakistan, Jamiat Ulema-e-Pakistan, Tehrik-e-Jafaria Pakistan and Jamiat Ahle Hadith did not participate and boycotted general election of 2008. Despite many celebrations of elections in Pakistan for democratization, there were serious question arise about the legitimate scope and range of authority of democratic institutions among political scientists and theorists. The election contesting candidate's scrutiny process was defective in Pakistan. There were no check and balance on the loan defaulters to contest elections. There were serious allegations on the voter lists in Pakistan.Gerry Mendering was principle adopted in this election against free and fair election.

Table No 4

Provincial Assemblies

\begin{tabular}{|l|l|l|l|l|}
\hline Province & General Seats & Seats for Women & Seats for Technocrats & Total Seats \\
\hline Punjab & 297 & 66 & 27 & 390 \\
\hline Sindh & 130 & 29 & 12 & 171 \\
\hline KPK & 99 & 22 & 09 & 130 \\
\hline Baluchistan & 51 & 11 & 05 & 67 \\
\hline Total Seats & 577 & 128 & 53 & 758 \\
\hline
\end{tabular}

Source: Election Commission of Pakistan.

Seats were reserved for women because women were not elected in general elections. Political parties were not giving opportunities to contest election on general seats. The half 
population segment was without representation in parliament. The women representation was not ignored in modern world.

Table No 5

Seats of National Assembly

\begin{tabular}{|l|l|l|l|l|}
\hline \multicolumn{1}{|c|}{ Province } & General Seats & Seats for Women & Seats for Technocrats & Total Seats \\
\hline Punjab & 148 & 36 & 15 & 198 \\
\hline Sindh & 61 & 14 & 6 & 81 \\
\hline KPK & 35 & 8 & 3 & 46 \\
\hline Baluchistan & 14 & 3 & 1 & 18 \\
\hline Capital & 02 & - & - & - \\
\hline FATA & 12 & - & - & - \\
\hline Total & 272 & 69 & 25 & 357 \\
\hline
\end{tabular}

Source: Election Commission of Pakistan.

Table No 6

General Election 2008

\begin{tabular}{|l|l|l|l|l|l|}
\hline Party Name & National & $\begin{array}{c}\text { Punjab } \\
\text { Provincial } \\
\text { Assembly }\end{array}$ & $\begin{array}{l}\text { Sindh } \\
\text { Provincial } \\
\text { Assembly }\end{array}$ & $\begin{array}{l}\text { Baluchistan } \\
\text { Provincial } \\
\text { Assembly }\end{array}$ & $\begin{array}{l}\text { Khyber Pukhtoon } \\
\text { khwa Provincial } \\
\text { Assembly }\end{array}$ \\
\hline PPPP & 87 & 78 & 65 & 7 & 17 \\
\hline PML(N) & 66 & 101 & 0 & 0 & 5 \\
\hline PML(Q) & 38 & 66 & 9 & 17 & 6 \\
\hline MQM & 19 & 0 & 38 & 0 & 0 \\
\hline ANP & 10 & 0 & 2 & 1 & 31 \\
\hline MMA & 3 & 2 & 0 & 6 & 9 \\
\hline PML F & 4 & 3 & 7 & 0 & 5 \\
\hline BNP(A) & 1 & 0 & 0 & 5 & 0 \\
\hline
\end{tabular}




\begin{tabular}{|l|l|l|l|l|l|}
\hline $\operatorname{PPP}(\mathrm{S})$ & 1 & 0 & 0 & 0 & 5 \\
\hline NPP & 2 & 0 & 3 & 0 & 0 \\
\hline Independents & 27 & 35 & 1 & 10 & 18 \\
\hline Contested & 268 & 293 & 130 & 51 & 96 \\
\hline Total Results & 259 & 285 & 125 & 46 & 91 \\
\hline
\end{tabular}

Source: Election Commission of Pakistan

\section{The Regime of Pakistan People's Party}

It was opportunity for peoples to express their choice for formation of government. Co-Chairman of PPP formed a coalition government with alliance of PML-N under charter of democracy spirit. It was thought about future of ruling coalition was bright in Pakistan. Zardari announced policy of political reconciliation. He personally visited head quarter of MQM with belief that political parties together should resolve the problems of masses of Karachi. The coalition of PML-N and PPP broke out to restore judiciary with accordance of Murree Declaration. There was no role of parliament in decision making of Zardari. The decision making process was individual not institutional. In this regard meetings held between Nawaz Sharif and Prime Minister or Zardari in Dubai and London. The supreme institution of decision making was not aware about situation. There was no debate Parliament. This showed the political instability never allow to flourished democracy in Pakistan.

\section{Presidential Election, 2008}

Pakistan had a mixed political system for governance. Pakistan is a federal state with parliamentary system under Constitution of 1973. But different Martial law governments changed governing system, some-time presidential form of government as in Ayub regime, some-time semi presidential as in Zia regime by constitution engineering with eighth amendment. It was adopted in Musharraf regime with some modification and followed by President Asif Ali Zardari. Later on he gave back powers to parliament.

General Musharraf had to resign under the fear of impeachment by abrogation of constitution on October 12, 1999. President Musharraf resigned from presidency in August18, 2008 and exited political stage. ${ }^{\text {xlvii }}$ Under constitution Muhammad Soomro Chairman ${ }^{\text {xlviii }}$ of Senate of Pakistan took charge as Acting President on August 18, 2008 and according to constitutional requirement new president was to elect within 30 days.

Presidential Election was conducted by Election Commission of Pakistan on September 6, 2008 in Pakistan. ${ }^{\text {xlix }}$ The Electoral College for Presidential Election is Senate, National Assembly and Provincial Assemblies of four provinces of Pakistan. PEC announced schedule of Presidential Election. Political Parties announced their presidential candidates. Pakistan People Party's co-chairman Bilawal Bhutto Zardari and Asif Ali Zardari whose party was largest party in parliament wanted next president from their party. The ruling coalition 
discussed about Presidential Election. MQM announced the support of Sindhi President of PPP. PML-N on August 21, discussed about presidential candidate. PPP officially nominated Asif Zardari as presidential candidate. PML-N pulled out from coalition and announced Saeed-uz-Zaman Siddique as presidential candidate. Asif Ali Zardari was elected as president announced by Qazi Mohammad Farooq CEC. Pakistani elected president was controversial figure under the charges of corruption.

\section{President Zardari and Coalition Government}

In August 2008 Zardari was elected as president. He was authoritarian President of Pakistan under seventeenth amendment. It converted in authoritarian rule of Pervez Musharraf in which he gained powers of Prime Minister. On the other hand he was co-chairman of Pakistan Peoples Party. He presided over party meetings in President House Islamabad. He never tried symbolically to prove impartial President of Pakistan.

There were charges of corruption on Mr. Zardari in Benazir Bhutto government. In 2007 PPP and Pervez Musharraf negotiated in Dubai for the transition. There was made a deal between two parties. Unfortunately Benazir Bhutto was murdered in December 2007. Now Zardari had dual status. After coming in power it was decided to validate NRO by parliament. There were many politicians and bureaucrats' beneficiary under NRO. This issue polarized the political parties, PPP itself faced internal conflict. PML-N alleged that it was the process of legitimating the corruption. Pakistani Media had played a vital role at this issue for the sack of public awareness. This strong response had forced the government to withdrawal of these proposals. In December 2008 governments turned back and withdrew the proposals which damaged the credibility of Zardari government. A petition was launched in Supreme Court of Pakistan.

After presidential election 2008 Presidential Zardari visited USA to attend the UNO session from September 23 to 26, 2008. In this foreign visit President Zardari met President George W. Bush, Chinese President Hu Jintao and Indian Prime Minister Manmohan Singh who was agreed to peace talk in 2008. President Zardari visited China on October 14 to 17, 2008. He negotiated for foreign aid because Pakistan was in possibility of default in payments. At last a request was sent to IMF to bailout to increase foreign exchange reserves.

Supreme Court of Pakistan gave decision on PCO judges case on August14, 2009 in which PCO Judges had been sacked, packed sent back to home. These judges took oath under PCO of Pervez Musharraf in 2007 in Superior Courts of Pakistan. New judicial crisis came at scene on Islamabad at the issue of appointment of judges in Federal Shariat Court. The Chief Justice of Federal Shariat Court had refused to manage oath from new selected judges by President Asif Ali Zardari. These appointments were made against his recommendations. Mostly members of the legal sorority wreak a rat in the legal changes being painstaking for appointment of judges and it might be foreboding undemonstrative attack on autonomy of judiciary.

India-Pakistan relation once again turned below level after Mumbai attack in November 2008. It was claimed by India that Lashker-e-Taiba was involved. It was further demanded to hand over culprits to India. It was felt insurgent attack in Pakistan by India under the cover of 
Mumbai's attack tension. Such incidents affected the peace of region which has influence on the political system. President Asif Ali Zardari visited Ajmer Sharif on April 8, 2012 to minimize the tension between both countries.

In Zardari's regime it was concerned about the provincial autonomy. The parliamentary committee was assigned special task to over hall the constitution according the spirit of Constitution 1973. The historic achievements of Zardari regime are provincial autonomy, NFC award, the identity issue of Pukhtoons and Aghaz-e-Haqooq-e-Baluchistan. It was power sharing between provinces and federation.

\section{Eighteenth Amendment and Provincial Autonomy}

In parliament special committee was constituted in the supervision of Raza Rabbani, a senator, which was consisting of all parties' representation. The objective of this committee was to revise the constitution of Pakistan. There were great discussions about the revision of constitution. On April 19, 2010 President of Pakistan signed on the bill of eighteenth amendment. It was an historic moment when massive powers were transferred from president to prime minister. The powers of governors were transferred to provincial assemblies and chief ministers. Under eighteenth amendment name of Zia-ul-Haq was eliminated from constitution and Zia-ul-Haq's LFO. Concurrent list was abolished on April 8, 2010. This amendment was restored according to original spirit of Constitution of 1973. Efforts were made to give sole provincial autonomy to provinces of Pakistan.

There was great controversy between Judiciary and government of Pakistan. The government of Pakistan decided on September 25, 2010 that no letter will be written to Swiss Authority. Supreme Court was hearing the petition against NRO. NRO ordinance had not validated by parliament. Pakistan Supreme Court disqualified Prime Minister of Pakistan in NRO implementation case in Jun 2012. Further proceeding of NRO implementation case still continued. Next Prime Minister Raja Pervez Ashraf took oath from PPP and democratic process was ongoing. Different dates were fixed for NRO case.

It is seen that political system of India was affected under the influence of class and religion discrimination. The results are seen in different clashes between different religious groups in India. These clashes are in or out religions. After taking over the leadership Indian National Congress by Sonia Gandhi, Nehru's family supremacy over the politics observed the political scientists. It is against the democratic principles of modern world. The demise of Congress Party in India sharpen one of the oldest tensions existed in all states.

\section{References}

i.Government of India, Census of India 2001, http://www.censusindia.net/results/resultsmain.html. view January 2006.

ii Gill, M.S., (1998). India: Running the World's Biggest Election, Journal of Democracy 9.1 p. 164-168.

iii. Mahmmud, Tayyab. (1994). Jurisprudence of Successful Treason: Coup d'Etat \& Common Law. 27 Cornell Int'L L.J, p. 49, 56-57. Mahmmud, Tayyab, (1993). Praetorianism and 
Common Law in Post-Colonial settings: Judicial Responses to Constitutional Breakdown in Pakistan, Utah L. Rev. p.1225, 1245.

${ }^{\text {iv }}$.Hans, Kelsen. (1949). General Theory of Law and State, Anders Wedbeg Trans: Harvard University Press. Pp.116-119, 220-221, 368-369.

`. Mahmmud, Tayyab. (1994). Supra note 32, at 138-40. Mahmmud, Tayyab, (1993). Supra note 32 , at1302-06.

${ }^{\text {vi }}$ http://www.indiaonline.in/About/Profile/Politics/PoliticalHistory/index.html.

vii . Balagopal, K., (2001). Probing in The Political Economy of Agrarian Classes and Conflicts, Perspective. Hyderabad, pp. 102- 104.

viii. The Politics of Legal Defense, Frontier, Vol. 6, No 13 July.

ix . Dhavan, Rajiv, (2001). POTO: An Assault on Democracy, The Hindu, November 16, 2001.

x. POTO Is More Draconian than TADA. The Hindu, November 25, 2001.

${ }^{x i}$. Reddy, G.R. Chandhra. (2007). Fault Lines in Indian Democracy. New Dehli: A.P.H Publishing Corporation. pp.197-202.

xii. The President promulgated the Prevention of Terrorism Ordinance, 2001 on October 24, 2001. The bill to replace the ordinance could not be passed during the subsequent session because the Parliament was adjourned after the attack on parliament on December 13, 2001.

The Parliament promulgated the bill on December 30, 2001. The act was replaced by the joint session (Rajya Sabha rejected it) on March 26, 2002 and given assent by the President on March 28, 2002.

xiii. Post-Godhra toll: 254 Hindus, 790 Muslims. September 27, 2009.

http://www.expressindia.com/news/fullstory.php?newsid=46538. Retrieved September 25, 2009.

xiv . Reddy, G.R. Chandhra. (2007). pp 132-133.

xv S., Rose-Ackerman. (1978). Corruption: A Study in Political Economy. New York:

Academic Press. pp 5-6.

${ }^{x v i}$. Ibid. pp. 233-34.

xvii. Report of the National Commission to Review the Working of the Constitution, Volume 1, Section 1.3.1, P.4.

xviii. See, Mukarji, Nirmal,\& Arora, Balveer, (1992). Eds. Federalism in India, New Delhi:

Vikas , Khan, Rasheed-ud-din, (1992). Federal India, New Delhi: Vikas, Singh, Mahendra Prashad,(1992). From Hegemony to Multi-Level Federalism, India's Parliamentary-Federal 
System. India Journal of Social Science, 5 (July-September1992). p.263-288.

xix . Profile: Manmohn Singh.BBC News. March 30. 2009.

http://news.bbc.co.uk/1/hi/world.southasia/3725357.stm. Retrieved April 12, 1012

${ }^{x x}$. Waldman. (2004). India Swears in $13^{\text {th }}$ Prime Minister and First Sikh in Job. The New

York Times.

http://www.nytimes.com/2004/05/23/world.india-swear-in-13th-prime-minister-and-first-sikh -in-job.html?pagewanted $=1$

${ }^{x x i} . h t t p: / / w w w . f o r e i g n a f f a i r s . o r g / 20070301$ faessay86207/ashutosh-varshney/india-3/13/2007.

P.6

xxii . Reddy, G.R. Chandhra. (2007). op.cit. pp. 170-174.

xxiii . Menaka Gandhi vs Union of India, AIR 1978, S.C 597.

xxiv.

http://www.foreignaffairs.org/20070301faessay86207/ashutosh-varshney/india-3/13/2007.p.6 xxv .http:// www.scribed.com/doc/6027 4312/Lokpal- English- PDF.

xxvi. U.S India ink historic civilian nuclear deal. People's Daily. October 11, 2008.

http://english.peopledaily.com.cn/90001/90777/90852/6513319.html. Retrieved December11, 2008 .

xxvii Article 249. A resolution can authorize such legislation for a maximum period of one year, but it may be renewed.

xxviii.http://www.pakistan.org/Pakistan.constitution/post_12oct99/pco_1999html. 6-10-2008.

xxix. Ibid. p.34.

${ }^{x x}$ Baxter, Craig. (2004). Pakistan on the Brink. Karachi: Oxford University Press. pp 59-60. xxxi Ibid. p. 60.

xxxii . NAB, Chief Denies Action against Certain Politicians, Dawn, August 25, 2002.

xxxiii. Proposals of the Government of Pakistan on the establishment of Sustainable Federal

Democracy Package-I, II, (Chief Executive Secretariat, National Reconstruction Bureau

(NRB). June 26, 2002.

xxxiv . Dawn, March 9, 2002

xxxv . Dawn, October 9, 2002

xxxvi . Mahmood, M. Dilawer. (1992). The Judiciary and Politics in the Pakistan. Lahore:

Idrara-e- Mutakka-e- Tareek. p.35. 
xxxvii . Dawn, April 8, 2002

xxxviii . Dawn, April 15, 2002

xxxix . International Crisis Group, (2003). Pakistan: The Mullahs and Military, ICG Asia

Report 49 Islamabad/ Brussels: International Crisis Group. pp 17-18

${ }^{\mathrm{xl}}$. EU Election Observation Mission. (2002). Pakistan National and Provincial Assembly

Election. October 10, 2002. Final Report 47-48.

xli. Musharraf, General Pervez. (2006). In the Line of Fire: A Memoir, Pakistan. Free Press, (Google Books), P. 367-69. Retrieved May 17, 2012.

xlii. Kronstadt, Alan. (2005). Pakistan's Domestic Political Developments. Report No. RL

32615 Washington, D.C: Congressional Research Service, September 19, 2005. p.16, Analyst in Asian Affairs Foreign Affairs, Defense, and Trade Division.

http://www.fas.org/sgp/crs/row/RL32615 pdf.

xliii . Ibid. p.18

xliv. Profile: Shaukat Aziz. (STM). BBC South Asia Directorate. South Asia: BBC Pakistan. August 19, 2004. Retrieved June 26, 2012

${ }^{x l v}$. International Crisis Group, (2005). Pakistan's Local Polls: Shoring up Military Rule, Asia Briefing 43 Islamabad/Brussels: International Crisis Group, 2005. p.6.

http://www.crisisgroup.org/library/documents.asia/south_asia/b043_pakistan_s_local_polls_s horing_up_military_rule.pdf.

xlvi . Sattar, Abul. (August 28, 2006). Killing of Pakistani Tribal Chief sparks fury and fears of war. London: The Guardian. Retrieved February 24, 2012.

${ }^{x l v i i}$.Musharraf Quits as President to Avoid Impeachment. Bloombeerg. 14 July 2008.

http://www.bloomberg.com/apps/news?pid=20601087\&sid=au6PGtmU44E0\&refer=home.

Retrieved 18-08-2008.

xlviii . Soomro takes over as acting Pak President (2008). Press Trust of India. August 18, 2008.

xlix. Date set for Pakistan election, The Australian. Theaustralian.news.com.au. August 22, 2008. http://www.theaustralian.news.com.au/story/0,25197,24223939-2703,00html.

Retrieved 26-09 2008. 
${ }^{1}$ http://www.miamiherald.com/2011/12/30/2566779/pakistan-judicial-commission-to.html

\section{Copyright Disclaimer}

Copyright reserved by the author(s).

This article is an open-access article distributed under the terms and conditions of the Creative Commons Attribution license ( ). 